\title{
PEMBATASAN HAK POLITIK MANTAN TERPIDANA KORUPSI MENJADI CALON ANGGOTA LEGISLATIF DALAM PEMILIHAN UMUM 2019 DI INDONESIA
}

\author{
Yusron Munawir \\ Program Studi Hukum, Fakultas Hukum, Universitas Muhammadiyah Yogyakarta, Indonesia \\ Jl. Brawijaya, Tamantiro, Kasihan, Bantul, Yogyakarta \\ E-mail: yusronmunawir@gmail.com
}

\section{Info Artikel}

Diajukan: 16-11-2019

Direview: 12-12-2019

Direvisi: $\quad 31-12-2019$

Diterima: 31-12-2019

DOI: $10.18196 / \mathrm{mls} .1102$

\begin{abstract}
Abstrak
Undang Undang Dasar Negara Republik Indonesia 1945 Pasal 28J ayat (2) menentukan bahwa pembatasan hak setiap orang ditetapkan dengan undang-undang. Komisi Pemilihan Umum sebagai lembaga pelaksana pemilihan umum menetapkan Peraturan Komisi Pemilihan Umum Nomor 14 Tahun 2018 dan Peraturan Komisi Pemilihan Umum Nomor 20 Tahun 2018 yang mengatur larangan bagi mantan terpidana korupsi menjadi calon anggota legislatif. Adanya norma larangan
\end{abstract} tersebut juga menimbulkan ketidaksesuaian dengan Undang-Undang Nomor 7 Tahun 2017 tentang Pemilihan Umum. Oleh karena itu, penelitian ini berusaha menjawab pokok permasalahan tentang bagaimana pembatasan hak politik mantan terpidana korupsi menjadi calon anggota legislatif dalam peraturan perundang-undangan di Indonesia. Metode penelitian yang digunakan dalam penelitian ini adalah penelitian yuridis normatif dengan metode analisis kualitatif-deskriptif. Hasil penelitian ini adalah pembatasan hak politik mantan terpidana korupsi menjadi calon anggota legislatif diatur dalam Undang-Undang Nomor 7 Tahun 2017 tentang Pemilihan Umum, Peraturan Komisi Pemilihan Umum Nomor 30 Tahun 2018 dan Peraturan Komisi Pemilihan Umum Nomor 31 Tahun 2018 yang mengatur bahwa mantan terpidana korupsi boleh menjadi calon anggota legislatif dengan syarat harus bersedia secara terbuka dan jujur mengemukakan kepada publik bahwa yang bersangkutan merupakan mantan terpidana korupsi. Penelitian ini merekomendasika kepada Komisi Pemilihan Umum dalam menetapkan peraturan supaya memperhatikan asas kesesuaian antara jenis, hierarki, dan materi muatan peraturan perundang-undangan lainnya.

Kata kunci: hak politik, mantan terpidana, korupsi.

\section{Pendahuluan.}

Pemilu 2019 telah usai, berbagai persoalan mewarnai pesta demokrasi lima tahunan di Indonesia. Mulai dari persoalan persoalan hak politik mantan terpidana hingga persoalan kematian 554 orang petugas Kelompok Penyelenggara Pemungutan Suara (KPPS), Panitia Pengawas Pemilihan Umum (Panwaslu), dan Polisi yang bertugas pada saat Pemilu 2019. Persoalan hak politik mantan terpidana mencuat pasca diundangkannya Peraturan Komisi Pemilihan Umum (PKPU) No. 20 Tahun 2018 yang melarang mantan terpidana korupsi, bandar narkoba, dan kejahatan seksual terhadap anak untuk disertakan dalam seleksi bakal calon anggota DPR, DPD, DPRD Provinsi, dan DPRD Kabupaten/Kota. Timbul pro dan kontra di masyarakat, ada yang 
mengapresiasi atas larangan tersebut sebagai wujud dari semangat pemberantasan korupsi dalam penyelenggaraan Pemilu 2019, namun juga terdapat penolakan dari pihak-pihak yang berkepentingan. PKPU tersebut dipandang bertentangan dengan aturan hukum yang lebih tinggi, yakni UU Pemilu. Padahal tiga bulan sebelum diundangkannya PKPU No. 20 Tahun 2018, KPU sudah terlebih dahulu melarang mantan terpidana korupsi, bandar narkoba, dan kejahatan seksual terhadap anak untuk menjadi calon anggota DPD yang diatur dalam PKPU No. 14 Tahun 2018. Waktu itu tidak ada persoalan dan perdebatan yang mempertanyakan mengenai konstitusionalitas PKPU No. 14 Tahun 2018.

Alasan pencantuman pasal ini, Ketua KPU Arief Budiman mengatakan bahwa pihaknya punya alasan kuat melarang mantan koruptor ikut pemilu. Arief menyebut Pasal 240 UU Pemilu, salah satu syarat dalam pasal tersebut adalah bertakwa kepada Tuhan YME. ${ }^{1}$ Apa rinciannya? Ya salah satunya (bertakwa berarti) tidak korupsi itu, tidak melakukan perbuatan tercela" ujar Arief di Hotel Borobudur, Jakarta, Kamis tanggal 24 Mei 2018. ${ }^{2}$ Norma larangan bagi mantan terpidana korupsi menjadi calon anggota legislatif yang diatur dalam Pasal 4 ayat (3) PKPU No. 20 Tahun 2018 dan Pasal 60 ayat (1) huruf j PKPU No. 14 Tahun 2018 dianggap bertentangan dengan UU Pemilu. Pasal 240 ayat (1) huruf g UU Pemilu mengatur bahwa:

"tidak pernah dipidana penjara berdasarkan putusan pengadilan yang telah memperoleh kekuatan hukum tetap karena melakukan tindak pidana yang diancam dengan pidana penjara 5 (lima) tahun atau lebih, kecuali secara terbuka dan jujur mengemukakan kepada publik bahwa yang bersangkutan mantan terpidana."

Secara substantif, UU Pemilu tidak membatasi terkait hak politik para mantan terpidana untuk mendaftar sebagai bakal calon legislatif, yakni "sepanjang tidak dimaknai dikecualikan bagi mantan terpidana yang secara terbuka dan jujur mengemukakan kepada publik bahwa yang bersangkutan mantan terpidana." Namun terdapat batasan-batasan hak politik yang secara normatif melekat pada mantan terpidana korupsi menjadi calon legislatif.

Konstitusionalitas peraturan perundang-undangan diperlukan untuk menguji konsistensi dan kesesuaian substansi materi peraturan perundang-undangan, baik pasal, ayat, atau bagian dari peraturan perundang-undangan dengan prinsip dan jiwa UUD 1945. Oleh karena itu, pembatasan hak politik mantan terpidana korupsi oleh KPU menjadi pembelajaran ke depannya apakah sudah tepat pembatasan hak politik warga negara melalui instrumen hukum Peraturan KPU.

\footnotetext{
${ }^{1}$ Pasal 240 ayat (1) huruf b UU No. 7 Tahun 2017

${ }^{2}$ Pernyataan Arief Budiman, "Alasan Kuat KPU Larang Mantan Koruptor Nyaleg”, 24 Mei 2018, https://www.google.co.id/amp/s/m.viva.co.id/amp/berita/politik/1039721-alasan-kuatkpu-larang-mantan-koruptor-nyaleg., diakses tanggal 17 Agustus 2018.
} 


\section{Metode Penelitian.}

Jenis penelitian ini merupakan penelitian hukum normatif, yaitu penelitian hukum yang dilakukan dengan cara meneliti bahan pustaka atau data sekunder sebagai bahan dasar untuk diteliti dengan cara mengadakan penelusuran terhadap peraturan perundangan-undangan dan literatur yang berkaitan dengan permasalahan yang diteliti. ${ }^{3}$ Pokok kajian dalam penelitian ini adalah mengkaji Peraturan KPU No. 14 Tahun 2018 dan Peraturan KPU No. 20 Tahun 2018 terkait larangan bagi mantan terpidan korupsi menjadi caleg, UU Pemilu, dan UUD 1945 sebagai norma atau kaidah yang berlaku dalam masyarakat.

Data yang diperoleh dalam penelitian ini kemudian dianalisis dengan menggunakan metode: (1) Analisis Kualitatif, yaitu data-data yang diperoleh dari hasil penelitian kemudian dikelompokkan lalu dihubungkan dengan masalah yang diteliti menurut kualitas kebenarannya, sehingga menjawab permasalahan yang ada; (2) Analisis Deskriptif, yaitu menggambarkan dan menjelaskan data-data yang diperoleh dari penelitian kepustakaan. Dari analisis data tersebut, dilanjutkan dengan menarik kesimpulan metode induktif yaitu suatu cara berfikir khusus lalu kemudian diambil kesimpulan secara umum sehingga mampu menjawab rumusan masalah yang pada akhirnya dapat ditarik kesimpulan tentang pembatasan hak politik mantan terpidana korupsi menjadi calon anggota legislatif dalam peraturan perundang-undangan di Indonesia.

\section{Hasil dan Pembahasan.}

\subsection{Pembatasan Hak Politik Mantan Terpidana dalam Undang-Undang Nomor 7 Tahun 2017}

\subsubsection{Pembatasan Hak Politik Mantan Terpidana Melalui Undang-Undang dan Putusan Hakim}

Pasal 1 ayat (3) UUD 1945 menegaskan bahwa negara Indonesia adalah negara hukum. Artinya, Setiap tindakan pemerintah dan rakyatnya harus didasarkan pada peraturan perundang-undangan yang telah ada. Amandemen kedua UUD 1945 memberikan jaminan perlindungan Hak Asasi Manusia yang diatur dalam bab tersendiri Bab XA tentang HAM. Prosedur pembatasan hak seseorang juga dapat ditemukan dalam bab tersebut. Pembatasan hak dan kebebasan warga negara diatur dalam Pasal 28J ayat (2) UUD 1945 yang berbunyi:

"Dalam menjalankan hak dan kebebasannya, setiap orang wajib tunduk kepada pembatasan yang ditetapkan dengan undang-undang dengan maksud semata-mata untuk menjamin pengakuan serta penghormatan atas hak kebebasan orang lain dan untuk memenuhi tuntutan yang adil sesuai dengan pertimbangan moral, nilai-nilai agama, keamanan, dan ketertiban umum dalam suatu masyarakat demokratis.”

\footnotetext{
${ }^{3}$ Soerjono Soekanto dan Sri Mamudji, Penelitian Hukum Normatif (Suatu Tinjauan Singkat), (Jakarta: Rajawali Pers, 2001), hlm. 13.
} 
Ketentuan lebih lanjut dapat ditemukan dalam UU No. 39 Tahun 1999 tentang Hak Asasi Manusia (UU HAM), tepatnya Pasal 73 yang berbunyi:

"Hak dan kebebasan yang diatur dalam undang-undang ini hanya dapat dibatasi oleh dan berdasarkan undang-undang, semata-mata untuk menjamin pengakuan dan penghormatan terhadap hak asasi manusia serta kebebasan dasar orang lain, kesusilaan, ketertiban umum, dan kepentingan bangsa."

Hak untuk memilih dan dipilih merupakan bagian dari HAM. Dalam penerapannya harus dipertimbangkan dampaknya terhadap terpidana dan masyarakat. Khusus penerapannya terhadap korupsi yang pelakunya memiliki kewenangan dalam mengelola negara, baik eksekutif maupun legislatif yang memiliki jaringan politik. Fungsinya untuk menghindarkan lembaga negara dipimpin oleh koruptor pada masa mendatang. Namun implementasinya tetap mendasarkan peraturan perundangan yang berlaku, yaitu adanya pembatasan pelaksanaan pencabutan hak politik sesuai dengan perundangan yang berlaku. ${ }^{4}$

Ketentuan dalam KUHP Pasal 10 huruf b, salah satu pidana tambahan adalah pencabutan hak-hak tertentu. Kemudian diatur lebih lanjut dalam Pasal 38 ayat (1) dan ayat (2) KUHP:

(1) Jika dilakukan pencabutan hak, hakim menentukan lamanya pencabutan sebagai berikut:

1. dalam hal pidana mati atau pidana penjara seumur hidup, lamanya pencabutan seumur hidup;

2. dalam hal pidana penjara untuk waktu tertentu atau pidana kurungan, lamanya pencabutan paling sedikit dua tahun dan paling banyak lima tahun lebih lama dari pidana pokoknya.

3. dalam hal pidana denda, lamanya pencabutan paling sedikit dua tahun dan paling banyak lima tahun.

(2) Pencabutan hak dimulai berlaku pada hari putusan hakim dapat dijalankan.

Terdapat pula ketentuan dalam UU No. 31 Tahun 1999 tentang Pemberantasan Tindak Pidana Korupsi, Pasal 18 ayat (1) huruf d yang berbunyi: "pencabutan seluruh atau sebagian hak-hak tertentu atau penghapusan seluruh atau sebagian keuntungan tertentu, yang telah atau dapat diberikan oleh Pemerintah kepada terpidana."

Dengan demikian, pembatasan hak seseorang, dalam hal ini hak politik mantan terpidana hanya bisa dilakukan dengan peraturan yang selevel UU. Jadi untuk membatasi hak warga negara menjadi caleg itu harus diatur dengan UU, tidak bisa misalnya hanya dengan Peraturan KPU. Selain itu, pencabutan hak politik dapat juga

\footnotetext{
${ }^{4}$ Warih Anjari, Pencabutan Hak Politik Terpidana Korupsi dalam Perspektif Hak Asasi Manusia, Jurnal Yudisial Vol. 8 No. 1 April 2015., hlm. 43.
} 
melalui putusan hakim, namun pidana tambahan berupa pencabutan hak politik itu harus dibatasi masa pencabutan haknya.

\subsubsection{Perubahan Norma Pembatasan Hak Politik Mantan Terpidana Pasca Putusan Mahkamah Konstitusi}

Pembatasan hak politik mantan terpidana untuk dapat menduduki jabatan publik telah mengalami beberapa perubahan norma yang diterapkan dalam beberapa UU. Fenomena perubahan norma terkait pembatasan hak politik mantan terpidana dapat dilihat pada 4 (empat) Putusan MK: pertama, Putusan MK No. 11-17/PUU-I/2003; kedua, Putusan MK No. 14-17/PUU-V/2007; ketiga, Putusan MK No. 4/PUU-VII/2009; dan keempat, Putusan MK No. 42/PUU-XIII/2015.

Pertama, Putusan MK No. 11-17/PUU-I/2003 melahirkan putusan yang mengecualikan terhadap mantan terpidana karena alasan politik, karena pembatasan tersebut bertentangan dengan UUD1945 Pasal 27 ayat (1), Pasal 28D ayat (1), Pasal 28I ayat (2) dan UU HAM Pasal 1 ayat (3). Dengan demikian, mantan terpidana karena alasan politik diperbolehkan menjadi caon anggota legislatif. Kedua, Putusan MK No. 14-17/PUU-V/2007, mengecualikan terhadap mantan terpidana karena kealpaan ringan dan karena alasan politik. Ketiga, Putusan MK No. 4/PUU-VII/2009, menetapkan putusan secara bersyarat terhadap mantan terpidana yang akan menjadi pejabat publik: (i) tidak berlaku untuk jabatan publik yang dipilih (elected officials); (ii) berlaku terbatas jangka waktunya hanya selama 5 (lima) tahun sejak terpidana selesai menjalani hukumannya; (iii) dikecualikan bagi mantan terpidana yang secara terbuka dan jujur mengemukakan kepada publik bahwa yang bersangkutan mantan terpidana; (iv) bukan sebagai pelaku kejahatan yang berulang-ulang.

Terakhir keempat, Putusan MK No. 42/PUU-XIII/2015, mengeluarkan putusan bersyarat bagi mantan terpidana yang secara terbuka dan jujur mengemukakan kepada publik bahwa yang bersangkutan mantan terpidana. Artinya putusan ini meniadakan syarat kedua dan syarat ketiga dari Putusan MK No. 4/PUU-VII/2009. Dengan demikian ketika seorang mantan terpidana selesai menjalankan masa tahanannya dan mengumumkan secara terbuka dan jujur bahwa dia adalah mantan terpidana, maka yang bersangkutan dapat mencalonkan diri menjadi gubernur, bupati, dan walikota atau mencalonkan diri menjadi calon anggota legislatif. Pada akhirnya, masyarakat yang memiliki kedaulatan lah yang akan menentukan pilihannya.

\subsubsection{Pembatasan Hak Politik Mantan Terpidana dalam Undang-Undang Nomor 7 Tahun 2017 tentang Pemilihan Umum}

Menyambut Pemilu Serentak, UU terkait pemilu yang sebelumnya tersebar dalam beberapa undang-undang, yakni UU No. 42 Tahun 2009 tentang Pemilu Presiden dan Wakil Presiden, UU No. 15 Tahun 2011 tentang Penyelenggara Pemilu, dan UU No. 8 Tahun 2012 tentang Pemilu DPR, DPD dan DPRD kemudian disatukan dan disederhanakan menjadi UU Pemilu, yakni UU No. 7 Tahun 2017. Selain itu, UU Pemilu ini juga sebagai tindak lanjut atas Putusan Mahkamah Konstitusi. 
Dalam UU Pemilu terdapat beberapa ketentuan pembatasan hak politik mantan terpidana yang hendak menjadi calon anggota legislatif, Presiden dan Wapres, KPU, dan Bawaslu. Klasifikasi pengisian jabatan di dalam UU Pemilu, yakni jabatan yang pengisiannya dipilih oleh rakyat secara langsung melalui pemilu (DPR, DPRD Provinsi, DPRD Kabupaten/Kota, DPD, Presiden dan Wakil Presiden). Kemudian ada juga jabatan yang pengisiannya dipilih dan diangkat oleh Tim Seleksi atau Lembaga lain, yakni KPU, PPK, PPS, KPPS, PPLN, KPPSLN, Bawaslu, Bawaslu Provinsi, Bawaslu Kabupaten/Kota, Panwaslu Kecamatan, Panwaslu Kelurahan/Desa, dan Pengawas TPS.

Pembatasan hak politik mantan terpidana dalam UU Pemilu terdapat perbedaan dalam hal pengisian jabatan publik, untuk jabatan yang dipilih dan jabatan yang diisi melalui pengangkatan atau dipilih Tim Seleksi. Untuk jabatan publik yang dipilih, calon anggota legislatif, mantan terpidana diperbolehkan dengan syarat harus bersedia secara terbuka dan jujur mengemukakan kepada publik bahwa yang bersangkutan mantan terpidana. Namun untuk jabatan presiden dan wakil presiden, mantan terpidana tidak diperbolehkan mencalonkan diri kecuali pidananya karena kealpaan atau alasan politik.

Untuk jabatan komisioner KPU dan Bawaslu, bagi mantan terpidana berlaku persyaratan sebagai berikut: (i) tidak berlaku untuk jabatan publik yang dipilih; (ii) berlaku terbatas jangka waktunya hanya 5 (lima) tahun sejak terpidana selesai menjalani hukumannya; (iii) dikecualikan bagi mantan terpidana yang secara terbuka dan jujur mengemukakan kepada publik bahwa yang bersangkutan mantan terpidana; (iv) bukan sebagai pelaku kejahatan yang berulang-ulang; (v) orang yang dipidana penjara karena alasan politik dikecualikan dari ketentuan ini.

Terdapat beberapa persoalan dalam UU Pemilu, pertama ditemukan beberapa Penjelasan Pasal yang melahirkan norma baru, yakni terkait persyaratan calon anggota KPU yang berlatar belakang mantan terpidana, Pasal 21 ayat (1) huruf 1 yang berbunyi: "tidak pernah dipidana penjara berdasarkan putusan pengadilan yang telah memperoleh kekuatan hukum tetap karena melakukan tindak pidana yang diancam dengan pidana penjara 5 (lima) tahun atau lebih.” Kemudian dalam Penjelasan Pasal 21 ayat (1) huruf 1 berbunyi:

Persyaratan ini berlaku sepanjang: (i) tidak berlaku untuk jabatan publik yang dipilih; (ii) berlaku terbatas jangka waktunya hanya 5 (lima) tahun sejak terpidana selesai menjalani hukumannya; (iii) dikecualikan bagi mantan terpidana yang secara terbuka dan jujur mengemukakan kepada publik bahwa yang bersangkutan mantan terpidana; (iv) bukan sebagai pelaku kejahatan yang berulang-ulang. Orang yang dipidana penjara karena alasan politik dikecualikan dari ketentuan ini.

Pembentuk UU Pemilu dinilai kurang memperhatikan teknik penyusunan peraturan perundang-undangan. Berdasarkan UU No. 12 Tahun 2011 tentang Pembentukan Peraturan Perundang-undangan Pasal 64 ayat (2) yang berbunyi: "Ketentuan mengenai teknik penyusunan Peraturan Perundang-undangan sebagaimana dimaksud pada ayat (1) tercantum dalam Lampiran II yang merupakan bagian tidak 
terpisahkan dari Undang-Undang ini." terdapat ketentuan mengenai Penjelasan dalam peraturan perundang-undangan, bahwa:

a. Penjelasan berfungsi sebagai tafsir resmi pembentuk Peraturan Perundangundangan atas norma tertentu dalam batang tubuh. Penjelasan hanya memuat uraian terhadap kata, frasa, kalimat atau padanan kata/istilah asing dalam norma yang dapat disertai dengan contoh. Penjelasan sebagai sarana untuk memperjelas norma dalam batang tubuh tidak boleh mengakibatkan terjadinya ketidakjelasan dari norma yang dimaksud.

b. Penjelasan tidak dapat digunakan sebagai dasar hukum untuk membuat peraturan lebih lanjut dan tidak boleh mencantumkan rumusan yang berisi norma.

c. Penjelasan tidak menggunakan rumusan yang isinya memuat perubahan terselubung terhadap ketentuan Peraturan Perundang-undangan.

Jadi dalam memberikan Penjelasan Pasal tidak diperbolehkan mencantumkan norma, apalagi menimbulkan norma baru. Penjelasan Pasal 21 ayat (1) huruf 1 UU Pemilu melahirkan norma baru bukan memperjelas norma Pasal dalam batang tubuh. Demikian halnya, Pasal 117 ayat (1) huruf 1 dengan Penjelasan Pasal 117 ayat (1) huruf 1 UU Pemilu. Mestinya norma baru yang dimuat dalam Penjelasan pasal di batang tubuh dituangkan pada poin berikutnya (ayat/huruf berikutnya) dalam pasal tersebut.

Kedua, terkait materi muatan UU Pemilu, ketika pembentuk UU Pemilu memberlakukan persyaratan calon anggota KPU yang berlatar belakang mantan terpidana harus memenuhi empat persyaratan sebagaimana dalam Penjelasan Pasal 21 ayat (1) huruf 1 UU Pemilu juga tidak tepat. Jabatan anggota KPU bukanlah merupakan jabatan publik yang dipilih sebagaimana yang dimaksud dalam Pendapat MK dalam Putusan No. 14-17/PUU-V/2007 dan Putusan No. 4/PUU-VII/2009 bahwa jabatan publik yang dipilih adalah jabatan publik yang pengisiannya dilakukan dengan cara pemilihan oleh rakyat. Sedangkan jabatan anggota KPU pengisiannya tidak dipilih melalui pemilihan oleh rakyat melainkan dipilih oleh Tim Seleksi yang dibentuk, jadi tidak tepat jika diberlakukan keempat syarat tersebut. Demikian halnya, dalam ketentuan persyaratan calon anggota Bawaslu yang dipilih melalui Tim Seleksi tidak bisa diberlakukan keempat syarat yang dimuat dalam Penjelasan Pasal 117 ayat (1) huruf 1 UU Pemilu.

Ketiga, inkonsistensi pembentuk UU Pemilu tampak ketika pembentuk UU Pemilu memberlakukan keempat syarat tersebut bagi mantan terpidana yang menjadi calon anggota KPU dan Bawaslu, namun tidak demikian ketika mempersyaratkan mantan terpidana yang menjadi calon anggota legislatif. Mantan

terpidana yang akan menjadi bakal calon anggota DPR, DPRD Provinsi, dan DPRD Kabupaten/Kota diatur dalam Pasal 240 ayat (1) huruf g UU Pemilu hanya 
mempersyaratkan harus bersedia secara terbuka dan jujur mengemukakan kepada publik bahwa yang bersangkutan mantan terpidana.

Keempat, UU Pemilu tidak mengatur persyaratan anggota DKPP, keanggotaan DKPP berjumlah 7 (tujuh) orang, yakni: a. 1 (satu) orang ex officio dari unsur KPU; b. 1 (satu) orang ex officio dari unsur Bawaslu; c. 5 (lima) orang tokoh masyarakat 2 (dua) orang diusulkan presiden dan 3 (tiga) orang diusulkan DPR). Untuk persyaratan lima orang dari tokoh masyarakat tidak ditentukan prosedur dan syaratnya. Mengingat DKPP memiliki kewenangan strategis dalam menangani pelanggaran kode etik Penyelenggara Pemilu, maka seyogyanya perlu adanya pengaturan prosedur dan persyaratan calon anggota DKPP yang akan diusulkan baik dari Presiden ataupun dari DPR.

\subsection{Pembatasan Hak Politik Mantan Terpidana Korupsi Menjadi Calon Anggota Legislatif dalam Pemilihan Umum 2019 di Indonesia}

\subsubsection{Pembatasan Hak Politik Mantan Terpidana Korupsi Menjadi Calon Anggota Legislatif dalam Peraturan KPU Nomor 14 Tahun 2018 dan Peraturan KPU Nomor 20 Tahun 2018}

Munculnya larangan bagi mantan terpidana korupsi oleh KPU menjadi awal persoalan dalam penelitian ini. Larangan tersebut terkait ketentuan teknis pencalonan anggota legislatif, KPU mengeluarkan Peraturan KPU (PKPU) No. 14 Tahun 2018 tentang Pencalonan Perseorangan Peserta Pemilihan Umum Anggota DPD dan Peraturan KPU (PKPU) No. 20 Tahun 2018 tentang Pencalonan Anggota DPR, DPRD Provinsi, dan DPRD Kabupaten/Kota. Kedua PKPU tersebut memuat aturan larangan bagi mantan terpidana bandar narkoba, kejahatan seksual terhadap anak, dan korupsi. Aturan tersebut ditetapkan KPU menjelang pendaftaran calon anggota legislatif pada Pemilu 2019.

Larangan mantan terpidana korupsi bagi calon anggota DPR, DPRD Provinsi, dan DPRD Kab/Kota semula diatur dalam Pasal 7 ayat (1) huruf h PKPU No. 20 Tahun 2018, akhirnya direvisi dan dipindah redaksinya ke dalam Pasal 4 ayat (3) yang berbunyi bahwa "Dalam seleksi bakal calon anggota legislatif yang dilakukan partai politik yang bersangkutan dilarang menyertakan mantan terpidana bandar narkoba, kejahatan seksual terhadap anak, dan korupsi." Norma tersebut dianggap bertentangan dengan Pasal 240 ayat (1) huruf g UU Pemilu, yang berbunyi:

Tidak pernah dipidana penjara berdasarkan putusan pengadilan yang telah memperoleh kekuatan hukum tetap karena melakukan tindak pidana yang diancam dengan pidana penjara 5 (lima) tahun atau lebih, kecuali secara terbuka dan jujur mengemukakan kepada publik bahwa yang bersangkutan mantan terpidana.

Sedangkan ketentuan larangan menjadi calon anggota DPD diatur dalam Pasal 60 ayat (1) huruf j PKPU Nomor 14 Tahun 2018, berbunyi bahwa:

Perseorangan peserta Pemilu dapat menjadi bakal calon perseorangan Peserta Pemilu Anggota DPD setelah memenuhi persyaratan: 
g. tidak pernah sebagai terpidana berdasarkan putusan pengadilan yang telah memperoleh kekuatan hukum tetap;

j. bukan mantan terpidana bandar narkoba, kejahatan seksual terhadap anak, atau korupsi.

Ketentuan tersebut dianggap bertentangan dengan Pasal 182 UU Pemilu, menetapkan bahwa:

Perseorangan sebagaimana yang dimaksud dalam Pasal 181 dapat menjadi Peserta Pemilu setelah memenuhi persyaratan:

g. tidak pernah dipidana penjara berdasarkan putusan pengadilan yang telah memperoleh kekuatan hukum tetap karena melakukan tindak pidana yang diancam dengan pidan penjara 5 (lima) tahun atau lebih, kecuali secara terbuka dan jujur mengemukakan kepada publik bahwa yang bersangkutan mantan terpidana.

\subsubsection{Pembatasan Hak Politik Mantan Terpidana Korupsi Menjadi Calon Anggota Legislatif dalam Perspektif Pemberantasan Korupsi di Indonesia}

KPU sebagai penyelenggara pemilu menjadikan UU No. 28 Tahun 1999 tentang Penyelenggaraan Negara yang Bersih dan Bebas dari Korupsi, Kolusi, dan Nepotisme sebagai acuan untuk menyusun larangan bagi mantan terpidana korupsi mendaftar sebagai calon anggota legislatif. Salah satu ketentuan UU tersebut mengatur tentang penyelenggaraan negara yang bersih dan bebas dari KKN. Pasal 5 angka 4 UU No. 28 Tahun 1999 disebutkan bahwa: "Setiap penyelenggara Negara berkewajiban untuk: 4. tidak melakukan perbuatan korupsi, kolusi, dan nepotisme." Aturan larangan calon anggota legislatif dari mantan terpidana korupsi merupakan bentuk perluasan penafsiran dari UU Pemilu. Memperluas yang dimaksud yaitu khususnya adalah memperluas tafsiran Pasal 240 ayat (1) huruf g UU Pemilu.

Dibutuhkan standar dalam persyaratan pencalonan legislatif di Negara Indonesia. Bahkan dalam hal masyarakat yang ingin melamar pekerjaan pun perlu menyertakan Surat Keterangan Catatan Kepolisian (SKCK). Hal tersebut bertujuan untuk mengetahui apakah orang tersebut pernah melakukan pidana. Apabila orang tersebut pernah melakukan tindak pidana, konsekuensinya adalah orang tersebut tidak akan terpilih. PKPU dapat memperlihatkan salah satu kegunaan SKCK dalam menyaring calon legislatif agar masyarakat hanya mendapatkan caleg yang terbaik. Oleh karena itu, KPU akhirnya memberlakukan PKPU larangan mantan terpidana korupsi untuk maju dalam Pemilu 2019.

Poin penting PKPU mengatur mengenai pelarangan mantan terpidana korupsi menjadi calon legislatif dalam Pemilu 2019 yaitu demi terwujudnya penyelenggaraan pemerintahan yang baik harus dikelola melalui pemerintahan yang bersih dan bebas dari KKN. Di sisi lain semangat pemberantasan korupsi juga perlu memperhatikan kaidah pembentukan perundang-undangan yang benar. Jika melihat kedudukan PKPU sebagai aturan pelaksana tentu harus memperhatikan UU yang memberikan atribusi kepadanya, 
yaitu UU Pemilu. Oleh karena itu, perlu adanya tinjauan terhadap PKPU tersebut apakah menabrak UU yang ada diatasnya atau tidak, melalui saluran pengujian ke Mahkamah Agung.

\subsubsection{Pembatasan Hak Politik Mantan Terpidana Korupsi Menjadi Calon Anggota Legislatif dalam Perspektif Hak Asasi Manusia}

Jaminan atas HAM harus tercantum dalam UUD atau konstitusi tertulis suatu negara, dan dianggap sebagai poin terpenting yang harus ada dalam sebuah konstitusi. ${ }^{5}$ HAM merupakan hak dasar atau hak pokok yang dimiliki manusia sejak lahir. ${ }^{6}$ Definisi HAM adalah hak yang melekat pada hakekat dan keberadaan manusia sebagai makhluk Tuhan YME dan merupakan anugerahnya yang wajib dihormati, dijunjung tinggi dan dilindungi oleh negara, hukum, pemerintah, dan setiap orang demi kehormatan serta perlindungan harkat dan martabat manusia. ${ }^{7}$

Terdapat hak asasi manusia yang tidak dapat dikurangi dalam keadaan apapun atau nonderogable rights, yaitu: hak untuk hidup, hak untuk tidak disiksa, hak kebebasan pribadi, pikiran dan hati nurani, hak beragama, hak untuk tidak diperbudak, hak untuk diakui sebagai pribadi dan persamaan di hadapan hukum, dan hak untuk tidak dituntut atas dasar hukum yang berlaku surut. ${ }^{8}$

Terkait hak politik mantan terpidana korupsi untuk menjadi calon anggota legislatif tidak termasuk HAM yang tidak dapat dikurangi dalam keadaan apapun. Sebagaimana yang telah disampaikan Ketua Komnas HAM Ahmad Taufik Damanik mengatakan tak ada pelanggaran HAM dalam PKPU yang melarang mantan koruptor menjadi calon anggota legislatif. Dia menilai hak politik masuk kategori HAM yang bisa dikurangi pemenuhannya sepanjang dilakukan untuk memenuhi kepentingan lain yang lebih mendesak. Secara prinsip itu tidak dilarang mengurangi hak-hak politik seseorang karena hak politik itu bukan HAM yang absolut. Terlebih KPU berkepentingan untuk menyelenggarakan pemilu yang berkualitas dengan diisi oleh para caleg yang berintegritas. Hal itu menjadi kepentingan umum yang lebih besar dan layak diperjuangkan, sehingga hak politik mantan koruptor juga bisa dikurangi. ${ }^{9}$

\footnotetext{
${ }^{5}$ Jimly Asshiddiqie, Pengantar Ilmu Hukum Tata Negara, (Jakarta: Rajawali Press, 2011), hlm.343.

${ }^{6}$ Mexsasai Indra, Dinamika Hukum Tata Negara Indonesia, (Bandung: Refika Aditama, 2011), hlm.167.

${ }^{7}$ Pasal 1 angka 1 UU No. 39 Tahun 1999.

${ }^{8}$ Pasal 4 UU Nomor 39 Tahun 1999.

${ }^{9}$ Pernyataan Ketua Komnas HAM Ahmad Taufik Damanik pada tanggal 7 Juni 2018, https://nasional.kompas.com/read/2018/06/07/06415711/komnas-ham-sebut-tak-ada-pelanggaran-hamdalam-larangan-eks-koruptor-jadi. Akses pada tanggal 15 Januari 2019.
} 


\subsubsection{Pembatasan Hak Politik Mantan Terpidana Korupsi Menjadi Calon Anggota Legislatif dalam Perspektif Hierarki Peraturan Perundang- undangan di Indonesia}

Dalam teori hukum, dipahami bahwa suatu norma tidak boleh bertentangan dengan norma yang ada di atasnya. Inilah yang dimaksud sebagai sistem hierarki norma hukum atau perundang-undangan. Hierarki secara sederhana dapat dimaknai sebagai tata tingkatan suatu aturan hukum. Idealnya pembentukan peraturan semestinya tidak boleh bertentangan dengan peraturan di atasnya. Pembentukan peraturan haruslah memperhatikan asas-asas peraturan perundangan yang salah satunya yaitu lex superior derogat legi inferior. ${ }^{10}$

Hans Nawiasky berhasil mengembangkan teori jenjang norma hukum yang dinamakannya "die Theorie vom Stufenor dnung der Rechtsnormen". Dikatakannya bahwa selain norma itu berlapis-lapis dan berjenjang-jenjang, norma hukum dari suatu negara itu juga berkelompok-kelompok, dan pengelompokkan norma hukum terdiri atas empat kelompok besar, yaitu: ${ }^{11}$

a. Kelompok I: Staatsfundamentalnorm (Norma Fundamental Negara);

b. Kelompok II: Staatsgrundgesetz (Aturan Dasar/Aturan Pokok Negara);

c. Kelompok III: Formell Gesetz (Undang-Undang); dan

d. Kelompok IV: Verordnung \& Autonome (Aturan Pelaksana/Otonom).

Dalam konteks ini, PKPU dapat dikatakan termasuk pada kelompok IV yang merupakan salah satu bentuk aturan pelaksana. Dikatakan aturan pelaksana karena kewenangan pembentukannya bersumber dari kewenangan atribusi. PKPU contohnya, sebagaimana diatur dalam Pasal 257 UU Pemilu bahwa "Ketentuan lebih lanjut mengenai pedoman teknis pencalonan anggota DPR, DPRD provinsi, dan DPRD kabupaten/kota diatur dalam Peraturan KPU”.

Lebih jauh lagi, asas mengenai struktur norma bahkan menjadi hukum positif yang diatur dalam UU No. 12 Tahun 2011. Dikatakan bahwa "Kekuatan hukum Peraturan Perundang-undangan sesuai dengan hierarki”. Apabila ada suatu norma hukum peraturan yang lebih rendah tingkatannya dipandang bertentangan dengan peraturan yang lebih tinggi, UU No. 12 Tahun 2011 juga telah memberikan solusi dengan dilakukannya mekanisme pengujian (uji materiil). Dalam konteks ini, maka jika PKPU dipandang bertentangan dengan UU Pemilu maka pengujiannya dilakukan di MA. $^{12}$

\footnotetext{
${ }^{10}$ Soekanto Soerjono dan Purnadi Purbacaraka, Perihal Kaidah Hukum, (Bandung: PT. Citra Aditya Bakti, 1993), hlm. 92.

${ }^{11}$ Maria Farida Indrati, Ilmu Perundang-undangan: Jenis, Fungsi, dan Materi Muatan, (Yogyakarta: Kanisius, 2007), hlm. 44.

${ }^{12}$ Pasal 9 ayat (2) UU No. 12 Tahun 2011.
} 


\subsubsection{Pembatasan Hak Politik Mantan Terpidana Korupsi Menjadi Calon Anggota Legislatif Pasca Putusan MA Nomor 30 P/HUM/2018 dan Putusan MA Nomor 46 P/HUM/2018}

Saluran pengujian peraturan perundang-undangan di bawah UU terhadap UU diuji lewat MA. ${ }^{13}$ Dalam hal ini, PKPU No. 14 Tahun 2018 dan PKPU No. 20 Tahun 2018 terhadap UU Pemilu. Atas pengujian tersebut, MA mengeluarkan Putusan MA No. 30 P/HUM/2018 dan Putusan MA No. 46 P/HUM/2018 yang menyatakan norma larangan mantan terpidana korupsi dalam kedua PKPU a quo bertentangan dengan UU Pemilu. Akibatnya calon mantan terpidana korupsi yang sebelumnya dinyatakan TMS maka harus dinyatakan Memenuhi Syarat, dengan syarat belum digantikan calon yg lain, pernah mengajukan sengketa ke Bawaslu dan hasilnya menang.

Sebagai tindak lanjut KPU maka menerbitkan PKPU No. 30 Tahun 2018 tentang Perubahan Ketiga atas PKPU No. 14 Tahun 2018 tentang Pencalonan Perseorangan Peserta Pemilu Anggota DPD dan PKPU No. 31 Tahun 2018 tentang Perubahan atas PKPU No. 20 Tahun 2018 tentang Pencalonan Anggota DPR, DPRD Provinsi, dan DPRD Kabupaten/Kota.. Kedua PKPU tersebut untuk mengakomodir caleg mantan terpidana koruptor. Berdasarkan Pengumuman KPU tanggal 30 Januari 2019 melalui Keputusan KPU No. 1129/PL.01.4-Kpt/06/KPU/IX/2018 dan Keputusan KPU No. 1734/PL.01.4-Kpt/06/IX/2018, tercatat 40 calon anggota DPRD Provinsi dan DPRD Kabupaten/Kota dan 9 calon anggota DPD yang lolos sebagai peserta Pemilu 2019. Namun kemudian pengumuman KPU berikutnya pada tanggal 19 Februari 2019 terdapat penambahan caleg mantan terpidana korupsi sebanyak 32 caleg sehingga menjadi 72 caleg DPRD Provinsi dan DPRD Kabupaten/Kota.

\subsubsection{Pembatasan Hak Politik Mantan Terpidana Korupsi Menjadi Calon Anggota Legislatif dalam Pemilihan Umum 2019 di Indonesia}

Pembatasan hak politik mantan terpidana korupsi menjadi calon anggota legislatif diatur dalam UU No. 7 Tahun 2017 tentang Pemilu kemudian diatur lebih lanjut melalui PKPU No. 14 Tahun 2018 dan PKPU No. 30 Tahun 2018 tentang perubahan ketiga atas PKPU No. 14 Tahun 2018 tentang Pencalonan Perseorangan Peserta Pemilihan Umum Anggota DPD. Terkait pengaturan pencalonan DPR diatur lagi dalam PKPU No. 20 Tahun 2018 dan PKPU No. 31 Tahun 2018 tentang Perubahan atas PKPU No. 20 Tahun 2018 tentang Pencalonan Anggota DPR, DPRD Provinsi, dan DPRD Kabupaten/Kota.

Pembatasan hak politik mantan terpidana korupsi menjadi calon legislatif dalam peraturan perundang-undangan di Indonesia diatur dalam UU Pemilu dan PKPU terbaru (PKPU No. 30 Tahun 2018 dan PKPU No. 31 Tahun 2018). Pada intinya, mantan terpidana korupsi diperbolehkan menjadi calon anggota legislatif dengan syarat harus bersedia secara terbuka dan jujur mengemukakan kepada publik bahwa yang bersangkutan merupakan mantan terpidana. Bukti kesediaan secara terbuka dan jujur

\footnotetext{
${ }^{13}$ Pasal 24A ayat (1) UUD 1945 Setelah Perubahan.
} 
mengemukakan kepada publik bahwa yang bersangkutan mantan terpidana adalah surat dari pemimpin redaksi media massa lokal atau nasional yang menerangkan bahwa bakal calon telah secara terbuka dan jujur mengemukakan kepada publik sebagai mantan terpidana dan bukti pernyataan atau pengumuman yang ditayangkan di media massa lokal atau nasional.

\section{Simpulan.}

\subsection{Simpulan}

Berdasarkan uraian pembahasan maka dapat disimpulkan, bahwa pembatasan hak politik mantan terpidana korupsi menjadi calon legislatif dalam Pemilihan Umum 2019 di Indonesia diatur melalui UU No. 7 Tahun 2017 tentang Pemilu, PKPU No. 30 Tahun 2018, dan PKPU No. 31 Tahun 2018. Ketiga regulasi tersebut mengatur mantan terpidana korupsi boleh menjadi calon anggota legislatif dengan syarat harus bersedia secara terbuka dan jujur mengemukakan kepada publik bahwa yang bersangkutan merupakan mantan terpidana korupsi. Bukti kesediaan secara terbuka dan jujur mengemukakan kepada publik berupa surat dari pemimpin redaksi media massa lokal atau nasional yang menerangkan bahwa bakal calon telah secara terbuka dan jujur mengemukakan kepada publik sebagai mantan terpidana korupsi dan bukti pernyataan/pengumuman yang ditayangkan di media massa lokal atau nasional.

\subsection{Saran}

Komisi Pemilihan Umum dalam menetapkan sebuah peraturan, ke depan supaya memperhatikan asas kesesuaian jenis, hierarki, dan materi muatan. Materi muatan yang dituangkan dalam Peraturan KPU tidak boleh bertentangan dengan materi muatan peraturan perundang-undangan yang ada di atasnya. Hal ini bertujuan untuk memberikan kepastian hukum dan harmonisasi peraturan perundang-undangan yang ada terkait pemilihan umum, sehingga tidak menimbulkan persoalan di masyarakat ke depannya.

\section{Daftar Pustaka}

\section{Buku}

Asshiddiqie, Jimly, 2011, Pengantar Ilmu Hukum Tata Negara, Edisi Pertama, Jakarta, Rajawali Grafindo Press.

Indrati, Maria Farida, 2007, Ilmu Perundang-undangan: Jenis, Fungsi, dan Materi Muatan, Yogyakarta, Kanisius.

Indra, Mexsasai, 2011, Dinamika Hukum Tata Negara Indonesia, Bandung, Refika Aditama.

Moeljatno, 1990, KUHP: Kitab Undang-undang Hukum Pidana, Jakarta, Bumi Aksara.

Soekanto, Soerjono dan Purnadi Purbacaraka, 1993, Perihal Kaidah Hukum, Bandung, PT. Citra Aditya Bakti. 
Soekanto, Soerjono dan Sri Mamudji, 2001, Penelitian Hukum Normatif: Suatu Tinjauan Singkat, Jakarta, Rajawali Pers.

\section{Jurnal}

Anjari, Warih, 2015, "Pencabutan Hak Politik Terpidana Korupsi dalam Perspektif Hak Asasi Manusia", Jurnal Yudisial, Vol. 8, No. 1.

\section{Regulasi}

Undang-Undang Dasar 1945 Setelah Perubahan.

Undang-Undang Nomor 7 Tahun 2017 tentang Pemilihan Umum.

Undang-Undang Nomor 12 Tahun 2011 tentang Pembentukan Peraturan Perundang-undangan.

Undang-Undang Nomor 39 Tahun 1999 tentang Hak Asasi Manusia.

Peraturan Komisi Pemilihan Umum Nomor 14 Tahun 2018 tentang Pencalonan Perseorangan Peserta Pemilihan Umum Anggota Dewan Perwakilan Daerah.

Peraturan Komisi Pemilihan Umum Nomor 20 Tahun 2018 tentang Pencalonan Anggota Dewan Perwakilan Rakyat, Dewan Perwakilan Rakyat Daerah Provinsi, dan Dewan Perwakilan Rakyat Daerah Kabupaten/Kota.

Peraturan Komisi Pemilihan Umum Nomor 30 Tahun 2018 tentang Perubahan Ketiga Atas Peraturan Komisi Pemilihan Umum Nomor 14 Tahun 2018 tentang Pencalonan Perseorangan Peserta Pemilihan Umum Anggota Dewan Perwakilan Daerah.

Peraturan Komisi Pemilihan Umum Nomor 31 Tahun 2018 tentang Perubahan Atas Peraturan Komisi Pemilihan Umum Nomor 20 Tahun 2018 tentang Pencalonan Anggota Dewan Perwakilan Rakyat, Dewan Perwakilan Rakyat Daerah Provinsi, dan Dewan Perwakilan Rakyat Daerah Kabupaten/Kota.

Putusan Mahkamah Agung Nomor 30 P/HUM/2018 tentang Pengujian Peraturan Komisi Pemilihan Umum Nomor 14 Tahun 2018 tentang Pencalonan Peserta Pemilihan Umum Anggota Dewan Perwakilan Daerah.

Putusan Mahkamah Agung Nomor 46 P/HUM/2018 tentang Pengujian Peraturan Komisi Pemilihan Umum Nomor 20 Tahun 2018 tentang Pencalonan Anggota Dewan Perwakilan Rakyat, Dewan Perwakilan Rakyat Daerah Provinsi, dan Dewan Perwakilan Rakyat Daerah Kabupaten/Kota.

\section{Website}

Arief Budiman, "Alasan Kuat KPU Larang Mantan Koruptor Nyaleg", 24 Mei 2018, https://www.google.co.id/amp/s/m.viva.co.id/amp/berita/politik/1039 721-alasan-kuatkpu-larang-mantan-koruptor-nyaleg-, diakses tanggal 17 Agustus 2018.

Ahmad Taufik Damanik, "Komnas HAM Sebut tak Ada Pelanggaran HAM dalam Larangan Eks Koruptor Jadi Caleg", 7 Juni 2018, https://nasional. kompas.com/read/2018/06/07/06415711/komnas-ham-sebut-tak-ada-pelan ggaran-hamdalam-larangan-eks-koruptor-jadi., diakses tanggal 15 Januari 2019.

Komisi Pemilihan Umum, "Daftar Lengkap 81 Caleg Eks Koruptor", 19 Februari 2019, https://nasional.kompas.com/read/2019/02/19/15075331/daftar-leng kap-81-caleg-ekskoruptor?page=1, diakses tanggal 1 April 2019. 